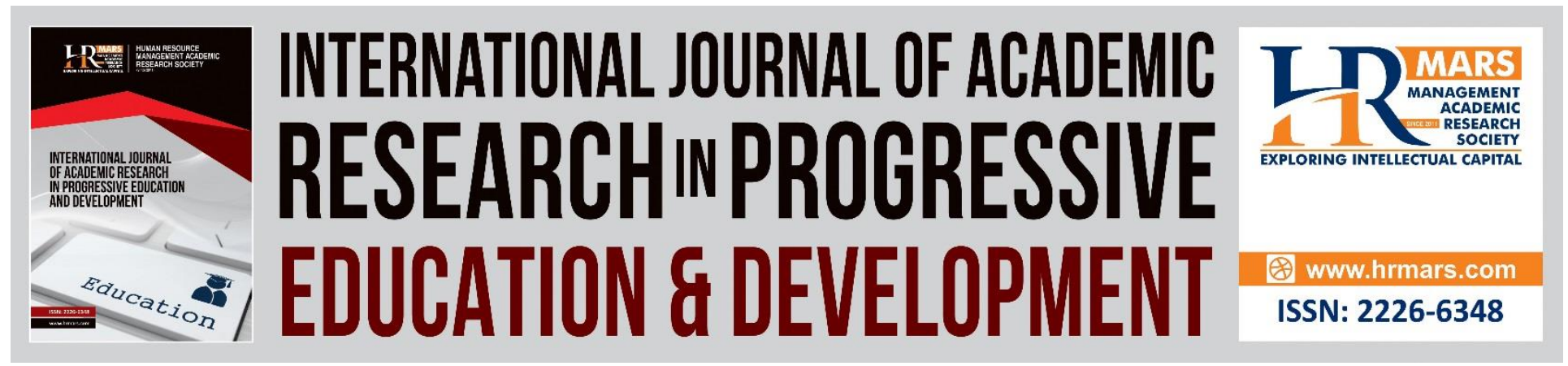

\title{
A Study of Motivating Language Usage by Leaders in Waqf Institutions in Malaysia
}

\author{
Sharfizie Mohd Sharip, Marinah Awang, Ramlee Ismail
}

To Link this Article: http://dx.doi.org/10.6007/IJARPED/v9-i2/7969

DOI:10.6007/IJARPED/v9-i2/7969

Received: 20 April 2020, Revised: 27 May 2020, Accepted: 18 June 2020

Published Online: 29 July 2020

In-Text Citation: (Sharip, Awang, \& Ismail, 2020)

To Cite this Article: Sharip, S. M., Awang, M., \& Ismail, R. (2020). A Study of Motivating Language Usage by Leaders in Waqf Institutions in Malaysia. International Journal of Academic Research in Progressive Education \& Development. 9(2), 740-746.

Copyright: (C) 2020 The Author(s)

Published by Human Resource Management Academic Research Society (www.hrmars.com)

This article is published under the Creative Commons Attribution (CC BY 4.0) license. Anyone may reproduce, distribute, translate and create derivative works of this article (for both commercial and non-commercial purposes), subject to full attribution to the original publication and authors. The full terms of this license may be seen

at: http://creativecommons.org/licences/by/4.0/legalcode

Vol. 9(2) 2020, Pg. 740 - 746

http://hrmars.com/index.php/pages/detail/IJARPED

JOURNAL HOMEPAGE

Full Terms \& Conditions of access and use can be found at http://hrmars.com/index.php/pages/detail/publication-ethics 


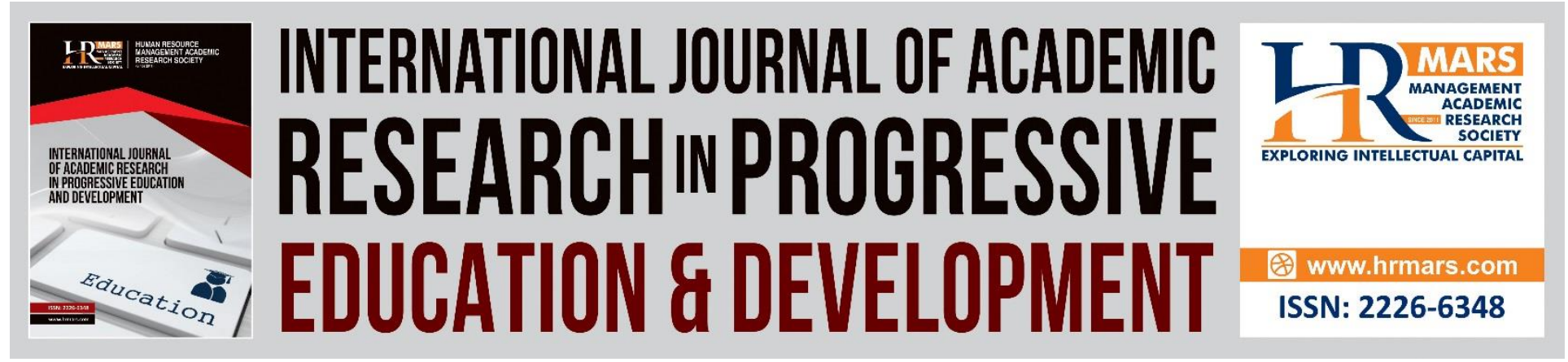

\title{
A Study of Motivating Language Usage by Leaders in Waqf Institutions in Malaysia
}

\author{
Sharfizie Mohd Sharip ${ }^{a}$, Marinah Awang ${ }^{b}$, Ramlee Ismailc \\ a Faculty of Business and Management, Universiti Teknologi MARA (UiTM), Rembau, 71300, \\ Malaysia, b,c Faculty of Management and Economics, Tanjung Malim,35900, Malaysia \\ Email: sharfizie@uitm.edu,my
}

\begin{abstract}
This article explores the level of motivating language usage among the leaders in Waqf institutions in Malaysia. Due to the identified ineffectiveness of Waqf institutions in handling Waqf properties, this study intends to examine the role of workplace communication in facilitating the leaders in determining the needed actions, conveying instructions and improving employee motivation. The study participants entail 162 full time employees in Waqf institutions in all the states throughout Malaysia. The findings reveal a high level of Direction-Giving Language and Empathetic Language usage among the leaders in the Waqf institutions, with only a moderate level of Meaning-Making Language usage. This paper facilitates understanding on the effect of motivational language usage by the leaders on management effectiveness.
\end{abstract}

Keywords: Waqf, Leader, Communication, Motivating Language, Malaysia.

\section{Introduction}

Leader communication has been identified as one of the most important workplace elements. Numerous studies have consistently shown the significant effect of leader communication on key organisational outcomes including effectiveness and productivity. Moreover, leader communication is also a pre-requisite for a well functioning workplace as a whole (Sharfizie et al., 2019a). The motivating language theory ( $\mathrm{ML}$ ) is a comprehensive communication framework developed as a communication strategies guideline for improving employee outcomes (Sullivan, 1988). Mayfield and Mayfield (2010) categorized motivating language into three namely direction-giving language, empathetic language and meaning-making language. Scholars have indicated that the usage of these motivating languages can lead to positive organisational outcomes (Mayfield \& Mayfield, 2007; Mayfield \& Mayfield, 2016).

The Motivating Language theory states that the desired outcomes of Motivating Language usage can only be achieved when all the three types of languages are used strategically (Madlock \& Sexton, 2015). However, Sullivan (1988) questioned the meaning of strategic usage. In fact, several studies have found that either one of the motivating languages can lead to positive 
outcomes. For instance, Madlock (2013) found that leaders in telecommuting often rely on direction-giving language whilst Kock et al. (2019) found that employees in US-based companies are positively affected by empathetic language usage. Most existing studies on motivating language are in the context of US-based companies (Madlock \& Sexton, 2015); very few had focused on Malaysian companies especially those in the non-profit sector (Sharfizie et al., 2019a). There is yet any significant research on the level of motivating language usage among leaders in Waqf institutions in Malaysia and its impact on management effectiveness. Thus, the main objective of this study is:

- To determine the level of Motivating Language (ML) dimension; Direction-Giving Language, Empathetic Language and Meaning-Making Language and Management Effectiveness in Waqf Institutions in Malaysia.

The research interest in this context is driven by the fact that in the Malay society, language is deemed to be reflective of the nation's level of civilization. The daily conversation among Malays is heavily influenced by the Islamic culture and religion (Nafisah, 2015). For the Malays, the concept of language is indistinguishable from Islamic values as Islamic teaching is a way of life that covers all aspects of the Malay culture (Bakari \& Kamaruddin, 2019). Islam teaches humility including in one's manner of talking and this is reflected in the beauty of the Malay culture (Hamid \& Iman, 2017). This suggests that the Malays generally prefer politeness and humbleness when conversing, an attribute that may drive self-motivation. Based on this argument, Malaysia is deemed as an apt research setting to better understand the motivating language $(\mathrm{ML})$ theory from a different perspective. Basically, there is no studies in a single framework have been carried out on the correlation between leader communication and Waqf management effectiveness in the context of Malaysia (Sharfizie et al., 2019b). In fact, past studies have also neglected to examine the level of motivating language usage among leaders either with a single type or with all three types simultaneously. This adds to the plausibility of exploring the usage level of each type of motivating language by leaders and their impact on the effectiveness of Waqf institutions in Malaysia.

\section{Methods}

This study utilizes the mono method i.e. the application of quantitative data analysis via selfadministered questionnaires. The census approach is deemed as more appropriate for the small population of Waqf officers throughout Malaysia, as the sampling approach would result in an out-count of the elements and thus the failure to represent the actual target group of respondents (Daniel, 2012). Furthermore, owing to the serious prevalence of management ineffectiveness in Waqf institutions in Malaysia, the reliability of this study's findings is expected to be attributed to census rather than sampling. Descriptive analysis is employed for analysing the gathered data and obtaining the needed information (Zikmund et al., 2009). It also explains the basic features and summarizes the information in a coherent manner. This study also employs the Statistical Package for Social Sciences (SPSS) software for analysing the frequency, mean and standard deviation on top of the five level mean score scale developed by Ungku Norulkamar (2010). 
INTERNATIONAL JOURNAL OF ACADEMIC RESEARCH IN PROGRESSIVE EDUCATION AND DEVELOPMENT

Vol. 9, No. 2, 2020, E-ISSN: $2226-6348$ @ 2020 HRMARS

Table 1: A -5 Level Mean Score Scale

\begin{tabular}{cc}
\hline Mean & Level \\
\hline $1.00-2.19$ & Very Low \\
$2.20-3.39$ & Low \\
$3.40-4.59$ & Moderate \\
$4.60-5.79$ & High \\
$5.80-7.00$ & Very High \\
\hline
\end{tabular}

\section{Results}

The results revealed a high level of direction-giving language (DGL) and empathetic language (EL) usage based on the 5-point scale with a mean range of between 4.60 and 5.79 (Ungku Norulkamar, 2010). Meanwhile, meaning-making language (MML) usage is revealed to be moderate based on the 5-point scale with a mean range of between 3.40 and 4.59 (Ungku Norulkamar, 2010). Table 2 summarizes the mean and level for each construct.

Table 2: The Summarization of Mean for each Construct

\begin{tabular}{llll}
\hline Construct & Mean & Std. Deviation & Level \\
\hline Direction Giving-Language (DGL) & 4.77 & 1.15 & High \\
Empathetic Language (EL) & 5.23 & 1.09 & High \\
Meaning-Making Language (MML) & 4.45 & 1.31 & Moderate
\end{tabular}

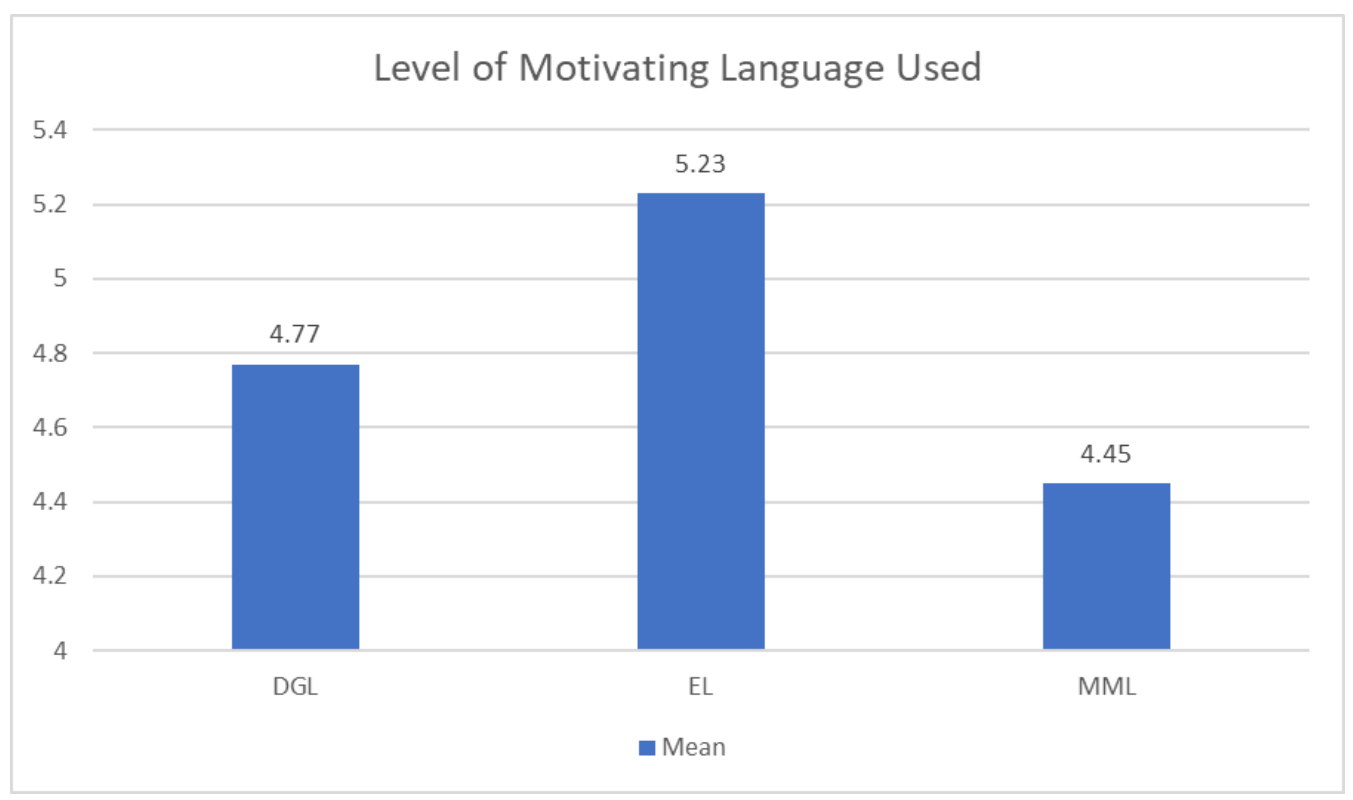

Figure 1: The Level of Motivating Language Used 


\section{Discussion/Conclusion}

The results revealed high mean scores for direction-giving language (DGL) and empathetic language (EL) i.e. 4.77 and 5.23 respectively, and a moderate mean score for meaning-making language ( $M M L)$ i.e. 4.55. Overall, the results reveal that leaders in Waqf institutions in Malaysia practice a high level of motivating language (ML) usage (4.76) and that the employees are highly affected by such communication strategies in steering their progress towards achieving positive organisational outcomes. Mayfield and Mayfield (2016) defined ML as a leader's oral communication strategy that can lead to positive employee outcomes. The high level of motivating language usage in the Waqf institutions could be due to a number of factors such as the culture and nature of the work environment in the institutions.

According to Ansari et al., (2004) leadership in a high contextual culture such as that of Malaysia tends to be hierarchical with a need to gradually develop the leader-employee relationship. Hofstede (1991 as cited in Ansari et al., 2004) asserted that Malaysia practices a collectivism culture i.e. "a situation in which people belong to certain groups or collectivises that will look after the members in exchange for their loyalty" (Hofstede \& Bond, 1984, p. 419). This present study reports a high mean score for direction-giving language (DGL) (4.77), reflecting a high level of leader-employee trust in the Waqf institutions. Meanwhile, Kolzow (2014) indicated that higher employee performance is demonstrated when the leader provides direct instructions which lead to the creation of a high level of trust within the organization. This study reveals that an effective leader gives out clear directions and organisational workflows as well as distinct expectations out of each employee. Clear descriptions of employee responsibilities are also important to prevent role ambiguities as well as to drive transparency and accountability. Thus, it is consistent with Sharfizie et al., (2019a) that mention clear and concise leader communication enhances organizational effectiveness and productivity. Persistent role ambiguities cause employees to interpret their responsibilities wrongly, ultimately leading to management ineffectiveness. The current findings also indicate that the leaders in the Waqf institutions use a high level of empathetic language (EL) with a mean score of 5.23. Leaders must demonstrate empathy when their subordinates are facing difficulties in performing their duty rather than putting the blame on them for mistakes or unachieved objectives. By having empathy, the leader can identify the root cause of the employees' poor performance and subsequently provide the needed assistance. An empathetic leader makes an effort to understand the feelings and views of his subordinates; this allows him to communicate and cooperate more effectively with them, thus stimulating their emotional intellect.

In terms of meaning-making language (MML) usage by the leaders in the Waqf institutions, the results revealed a moderate level with a mean score of 4.45 . This indicates the perception of the employees that their leaders are only averagely capable in delivering effective messages or instructions. To improve employee motivation, a leader should use real life examples in driving impactful messages. In the context of Waqf institutions, the leaders can use the Abbasiyah government as a powerful example of an administration that was capable of generating a massive wealth of 900 million dirham and 1.3 trillion dirham in properties from Waqf funding (Lajim, 2018). By using such examples as the benchmark of success, the leaders are providing a general idea of their expectations. 
Overall, the findings provide valuable insighs for the leaders in Waqf institutions about how the usage of suitable leadership language can improve management effectiveness. Nevertheless, the depth of the results has been limited by the quantitative approach used in this study which only provides numerical instead of detailed descriptions. Numerical descriptions do not provide a comprehensive picture of the employees' actual feelings about the research subject. Therefore, future studies could resort to using a qualitative method which is more flexible. This approach enables the researcher to do quick modifications on the questions, the setting or variables to achieve improved responses particularly when valuable insights are not captured. This method also enables the explanation of certain aspects that are unjustifiable by numbers.

At the same time, the ML suggests that leaders must use all three types of motivating language to attain their full benefit, but this research demonstrated that each of the motivating language contributes its own significant impacts. Very few studies had attempted to investigate the multidimensionality of $\mathrm{ML}$ in the context of Malaysian organisations. Hence, this study offers a new contribution to the literature by exploring the multidimensionality of $\mathrm{ML}$ and management effectiveness in the Malaysian context. In short, this research adds new insights to the existing literature pertaining to the multidimensionality of $\mathrm{ML}$

\section{References}

Ansari, M. A., Ahmad, Z. A., \& Aafaqi, R. (2004). Organizational Leadership in the Malaysian Context. In Leading in High Growth Asia: Managing Relationship for Teamwork and Change (pp. 109-138). World Scientific Publishing Co. Pte. Ltd. https://doi.org/10.1142/9789812562135

Bakari, A. M., \& Kamaruddin, R. (2019). Prinsip Kesopanan dalam Kesantunan Bahasa Drama Zahira. International Journal of the Malay World and Civilisation, 7(1), 15-26.

Daniel, J. (2012). Choosing Between Taking a Census and Sampling. SAGE Publications, Inc. https://doi.org/https://dx.doi.org/10.4135/9781452272047

Hamid, A., \& Iman, M. (2017). Waqf as a framework for entrepreneurship. Humanomics, 33(4), 419-440. https://doi.org/10.1108/H-01-2017-0015

Hofstede, G., \& Bond, M. H. (1984). Hofstede's Culture Dimensions: An Independent Validation Using Rokeach's Value Survey. Journal of Cross-Cultural Psychology, 15, 417-433. https://doi.org/10.1177/0022002184015004003

Kock, N., Mayfield, M., Mayfield, J., Sexton, S., \& Garza, L. M. D. La. (2019). Empathetic Leadership : How Leader Emotional Support and Understanding Influences Follower Performance. Journal of Leadership \& Organizational Studies, 26(2), 217-236. https://doi.org/10.1177/1548051818806290

Kolzow, D. R. (2014). LEADING FROM WITHIN : Building Organizational Leadership Capacity. https://www.iedconline.org/clientuploads/Downloads/edrp/Leading_from_Within.pdf

Lajim, F. (2018). Harta Wakaf Boleh Dimajukan, Dinikmati Bukan Islam. Berita Harian Online. https://www.bharian.com.my/rencana/agama/2019/05/561431/berwakaf-patutdijadikan-budaya-hidup

Madlock, P. E. (2013). The influence of motivational language in the technologically mediated realm of telecommuters. Human Resource Management Journal, 23(2), 196-210. https://doi.org/10.1111/j.1748-8583.2012.00191.x 
INTERNATIONAL JOURNAL OF ACADEMIC RESEARCH IN PROGRESSIVE EDUCATION AND

DEVELOPMENT

Vol. 9, No. 2, 2020, E-ISSN: $2226-6348$ @ 2020 HRMARS

Madlock, P. E., \& Sexton, S. (2015). An Application of Motivating Language Theory in Mexican Organizations. Journal of Business Communication, 52(3), 255-272. https://doi.org/10.1177/2329488415572783

Mayfield, J., \& Mayfield, M. (2007). The Effects of Leader Communication on a Worker' s Intent to Stay : An Investigation Using Structural Equation Modeling. Human Performance, 20(2), 85-102. https://doi.org/10.1080/08959280701332018

Mayfield, J., \& Mayfield, M. (2010). Leader-level influence on motivating language: A two-level model investigation on worker performance and job satisfaction. Competitiveness Review, 20(5), 407-422. https://doi.org/10.1108/10595421011080788

Mayfield, J., \& Mayfield, M. (2016). The Diffusion Process of Strategic Motivating Language : An Examination of the Internal Organizational Environment and Emergent Properties. International Journal of Business Communication, 1-25. https://doi.org/10.1177/2329488416629093

Mayfield, M., \& Mayfield, J. (2016). The Effects of Leader Motivating Language Use on Employee Decision Making. International Journal of Business Communication, 53(4), 465-484. https://doi.org/10.1177/2329488415572787

Nafisah, A. H. (2015). Kesantunan Bahasa - Penggunaan Sistem Sapaan Dan Eufemisme Dalam Komunikasi. In Perkongsian Profesional Bagi Guru-Guru Permulaan. (pp. 6-35). Pusat Bahasa Melayu Singapura, Kementerian Pendidikan Singapura.

Sharfizie, M. S., Marinah, A., \& Ramlee, I. (2019a). Conceptualizing the impact of Leadermember Exchange in non-profit and religious organisations : The case of waqf institutions in Malaysia. Journal of Emerging Economies \& Islamic Research 7(3), 7(3), 71-85.

Sharfizie, M. S., Marinah, A., \& Ramlee, I. (2019b). Management Effectiveness in Waqf Institutions in Malaysia : A Literature Review Management Effectiveness in Waqf Institutions in Malaysia : A Literature Review. International Journal of Academic Research in Business and Social Sciences, 9(11), 254-271. https://doi.org/10.6007/IJARBSS/v9-i11/6546

Sullivan, J. J. (1988). Three in Roles of Motivation Language Theory University of Washington. Academy of Management Review, 13(1), 104-115.

Norulkamar, U. A. (2010). Technostress and Organisational Commitment Among Librarians In The Malaysian Public Higher Learning Institutions. PhD Thesis, Universiti Teknologi Malaysia.

Zikmund, W. G., Babin, B. J., Carr, J. C., \& Griffin, M. (2009). Business Research Methods (8th Editio). South-Western College Pub. 